\title{
RESOLVER-TO-DIGITAL CONVERTERS WITH THE ARCTANGENT FUNCTION TRANSFORMATION
}

\author{
A.P. Balkovoy1, balk1954@yahoo.com, \\ E.V. Yurasova², iurasovaev@susu.ru, \\ Yu.S. Smirnov', smirnovys@susu.ru \\ ${ }^{1}$ Moscow Power Engineering Institute, Moscow, Russian Federation, \\ ${ }^{2}$ South Ural State University, Chelyabinsk, Russian Federation
}

\begin{abstract}
The work is devoted to the peculiarities of the construction of amplitude converters of type "angle-parameter-code", in which arctangent function transformation is used when converting output signals of a resolver into a digital equivalent of movement. The features of the construction of brushless classical resolvers and varieties of their variable reluctance, in Russia known as reductosin, are considered. It allows to realize an electrical reduction, at which the sensor accuracy increases considerably. The principle of operation of the resolver, output signals of which contain reliable information about components of displacement of the rotor, is found out. Resolver-to-Digital Converter (RDC) corresponds to the postulate of the general theory of relativity on communication of space and time.

A special place among one-component "angle-parameter-code" converters is held by the structures using arctg-conversion, at which quadrant or octant range splitting of the transformation of angular displacement is used. In the first case, angular transformation is implemented by the digital signal processor (DSP) or microcontroller, and in the second one - by ROM with arctg insertion.

The structure and ratios necessary for calculation of movement by software and tabular implementation of arctangent function transformation. An original version of the analog-to-digital converter with arctg ROM is presented. Its capacity at identical length of the output code is four times less than the capacity of traditionally used ROM with a sine-cosine firmware. Octant representation of a full range transformation of the angle of rotation allows to generate an additional high order digit of the output code in comparison with a traditional quadrant band splitting. This not only improves the resolution of the conversion twice, but also simplifies coordination of samples at application of an electrical reduction with the reductosin.

Keywords: resolver-to-digital converters, classical and variable reluctance resolvers (reductosin), pulsewidth modulation, brushless motors, arctangent function transformation, ADC voltage ratios, read-only memory.
\end{abstract}

\section{Introduction}

The scope of work is actual as it is devoted to energy informatics (energoinformational interaction) [1] of the electric drive [2] and mechartonic systems (MS) [3]. The analysis of publications devoted to the development, research and implementation of a dateware of the process of the conversion of energy in the functional movement of the working mechanism, possessing property of a chronotope, provides the following tasks:

- features of the resolver functioning and its construction [4-10];

- formation of the Common Dateware on the basis of the conversion corresponding to the general theory of relativity in terms of the postulate of time and space communication [11-16];

- as sensors at Common Dateware are used inductive [17], optical [18] and magnetic-field [19] sensors. Most widely used are Synhros and Resolvers (R), possessing remarkable properties and high performance criteria $[2,7]$.

\section{Resolver is a 2-phase micromachine}

Resolvers are brushless type (Fig. 1) that is, the rotor excitation is ring transformer (RT) coupled to the shaft rotor winding. Many resolver applications operate with high speeds where the velocity error is significant source of measurement errors. Also, the signals of resolver are affected by the switching 


\section{Приборостроение, метрология}

noise due to pulse width modulation (PWM) of the motor inverter [3,4]. Paper represents a solution for measuring the resolver signals for electric drive application without being affected by the speed and the switching noise due to PWM of motor inverter.

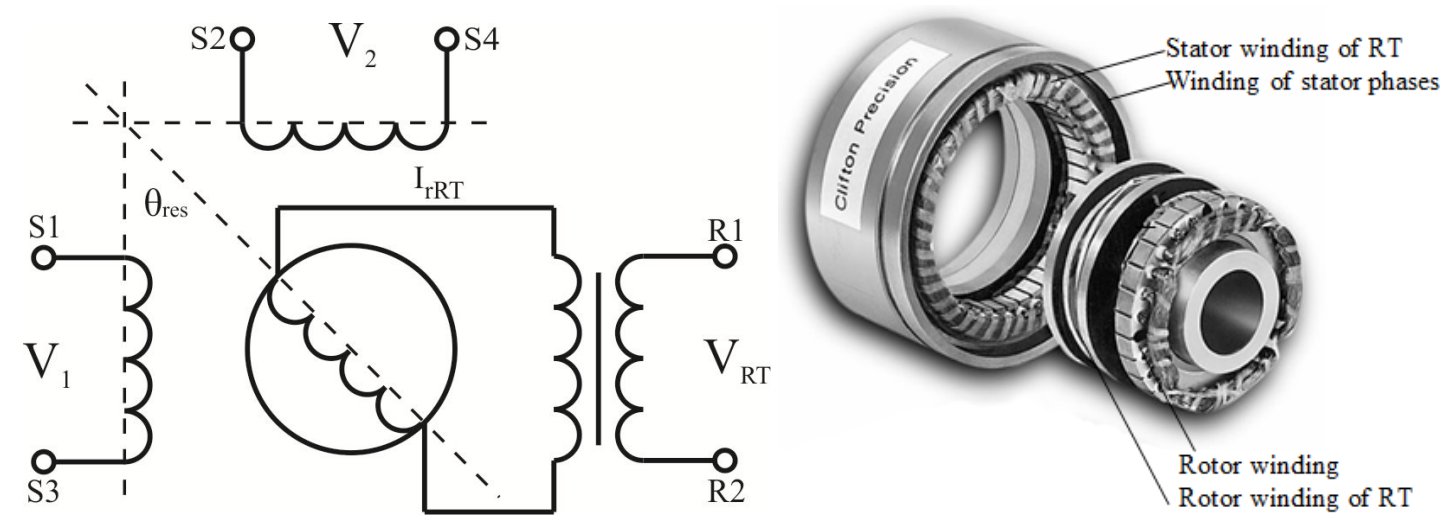

Fig. 1. The brushless classical resolver company Clifton Precision

The RT stator of brushless resolver (Fig. 1) is supplied from AC voltage $V_{R T}=V_{R T m} \sin \left(\Omega_{e} t+\varphi_{e}\right)$ of variable frequency $\Omega_{e}$ and phase shift of $\varphi_{e}$. The RT stator and rotor currents are $I_{S R T}$ and $I_{r R T}=I_{r R T m} \sin \left(\Omega_{e} t\right)$, respectively. Resolver is a 2-phase AC machine. So, the electrical equations for stator windings of this machine are:

$$
\begin{aligned}
V_{1} & =R I_{1}+L s I_{1}+s\left[\left(L_{m} \cos p_{r e s} \Theta_{m e}\right) I_{r R T}\right]= \\
& =R I_{1}+L s I_{1}-L_{m} I_{r R T} p_{r e s} \Omega_{m e} \sin p_{r e s} \Theta_{m e}+L_{m}\left(\cos p_{r e s} \Theta_{m e}\right)\left(s I_{r R T}\right) ; \\
V_{1} & =R I_{2}+L s I_{2}+s\left[\left(L_{m} \sin p_{r e s} \Theta_{m e}\right) I_{r R T}\right]= \\
& =R I_{2}+L s I_{2}+L_{m} I_{r R T} p_{r e s} \Omega_{m e} \cos p_{r e s} \Theta_{m e}+L_{m}\left(\sin p_{r e s} \Theta_{m e}\right)\left(s I_{r R T}\right),
\end{aligned}
$$

where $\Omega_{m e}$ is the mechanical speed; $\Theta_{m e}$ is the mechanical angle; $p_{r e s}$ is the resolver number of poles; $V_{1}, V_{2} ; I_{1}, I_{2}$ are the voltages and currents of stator 1 and 2 windings; $R$ is the stator winding resistance; $L$ is the stator winding inductance; $L_{m}$ is the amplitude of mutual inductance of stator windings and rotor winding; $s=d / d t$.

In the no-load condition (high impedance of measuring circuits), for stator windings there will be no current and the current derivatives will be also zero $\left(I_{1}=I_{2}=s I_{1}=s I_{2}=0\right)$. So, the equations (1) and (2) will be:

$$
\begin{aligned}
& V_{1}=L_{m}\left(\cos p_{r e s} \Theta_{m e}\right)\left(s I_{r R T}\right)-L_{m} I_{r R T} p_{r e s} \Omega_{m e}\left(\sin p_{r e s} \Theta_{m e}\right) ; \\
& V_{2}=L_{m} I_{r R T} p_{r e s} \Omega_{m e}\left(\cos p_{r e s} \Theta_{m e}\right)+L_{m}\left(\sin p_{r e s} \Theta_{m e}\right)\left(s I_{r R T}\right) .
\end{aligned}
$$

The voltages (3) and (4) have two components: the first one (back-EMF) depends of excitation frequency $\Omega_{e}$ (because $\left.I_{r R T}=I_{r R T m} \sin \Omega_{e} t\right)$, speed $\left(\Omega_{m e}\right)$ and position $\Theta_{\text {res }}=p_{\text {res }} \Theta_{m e}$, the second one (EMF of transformation) depends of frequency $\Omega_{e}$ (because $s I_{r R T}=I_{r R T m} \Omega_{e} \cos \Omega_{e} t$ ) and position $\Theta_{\text {res }}=p_{\text {res }} \Theta_{m e}$. This property of the signals $V_{1}$ and $V_{2}$ allows to eliminate errors due to the speed $\Omega_{m e}$. In the case of synchronous sampling of both signals $V_{1}$ and $V_{2}$ when $\sin \Omega_{e} t=0$ and $\cos \Omega_{e} t=1$, the current $I_{r R T}=0$ and its derivative is maximal: $s I_{r R T}=I_{r R T m} \Omega_{e} \cos \Omega_{e} t=I_{r R T m} \Omega_{e}$. So, in (3) and (4), the back-EMF components will be absent and EMFs of transformation will be only position dependent with maximal amplitude $V_{m}=L_{m} I_{r R T m} \Omega_{e}$ :

$$
\begin{aligned}
& V_{1}=L_{m}\left(\cos p_{r e s} \Theta_{m e}\right) I_{r R T m} \Omega_{e} ; \\
& V_{2}=L_{m}\left(\sin p_{r e s} \Theta_{m e}\right) I_{r R T m} \Omega_{e} .
\end{aligned}
$$

From (5) and (6), the angle $\Theta_{m e}=\Theta_{\text {res }} / p_{\text {res }}$ may be calculated using standard software decisions.

Variable reluctance resolvers (VRR) have no windings on the rotor. Their primary and secondary windings are all on the stator, but the saliency (exposed poles) of the rotor couples the sinusoidal variation in the secondary with the angular position Fig. 2) $[5,6]$. 

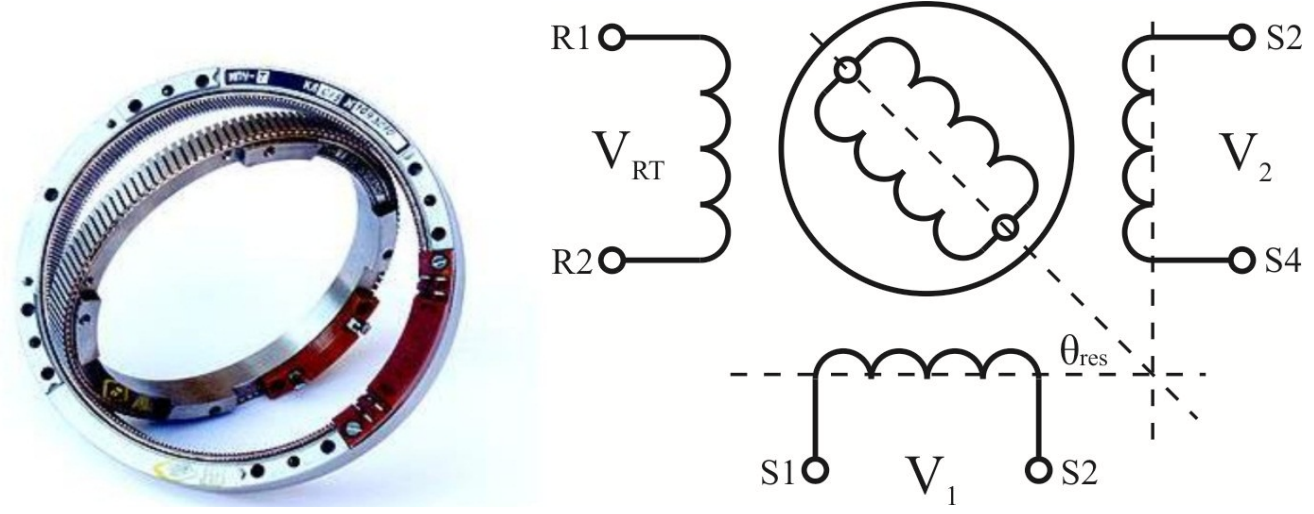

Fig. 2. Variable reluctance resolver (reductosin)

\section{The structure of the RDC with digital signal processor}

Converter realising the proposed method by $D S P$ comprises (Fig. 3): exciting generator $E G, D A C$ and analog voltage inverter $A V I$ for $\mathrm{R}$ excitation; differential amplifiers $D A 1$ and $D A 2$ conditioning resolver output signals; $A D C$ for converting of analog signals $V_{1}$ and $V_{2}$ into digital form $D_{1}$ and $D_{2}$; decoder software $D S W$ for calculating of resolver angle $\Theta_{\text {res }}=\Theta_{m e} p_{\text {res }}$ from $D_{1}$ and $D_{2}$.

RDC (Fig. 3) is capable of outputting a good resolver signals two times per excitation period without being affected by the motor speed and by the switching noise due to a PWM signal of an inverter. In the tested system, the 14-bit $\mathrm{AD}$ converter for data conversion was used. That means $(4 \mathrm{~V} / 5 \mathrm{~V}) \cdot 16392=13113$ bit resolution for peak-to-peak of the measured signal. There are $360 \times 60 \times 60^{\prime \prime}$ (arc seconds) in the 32 periods ( 2 times peak-to-peak) of the resolver with 32 poles signal. So, one bit (resolution) of the ADC corresponds to 1,544" (arc seconds).

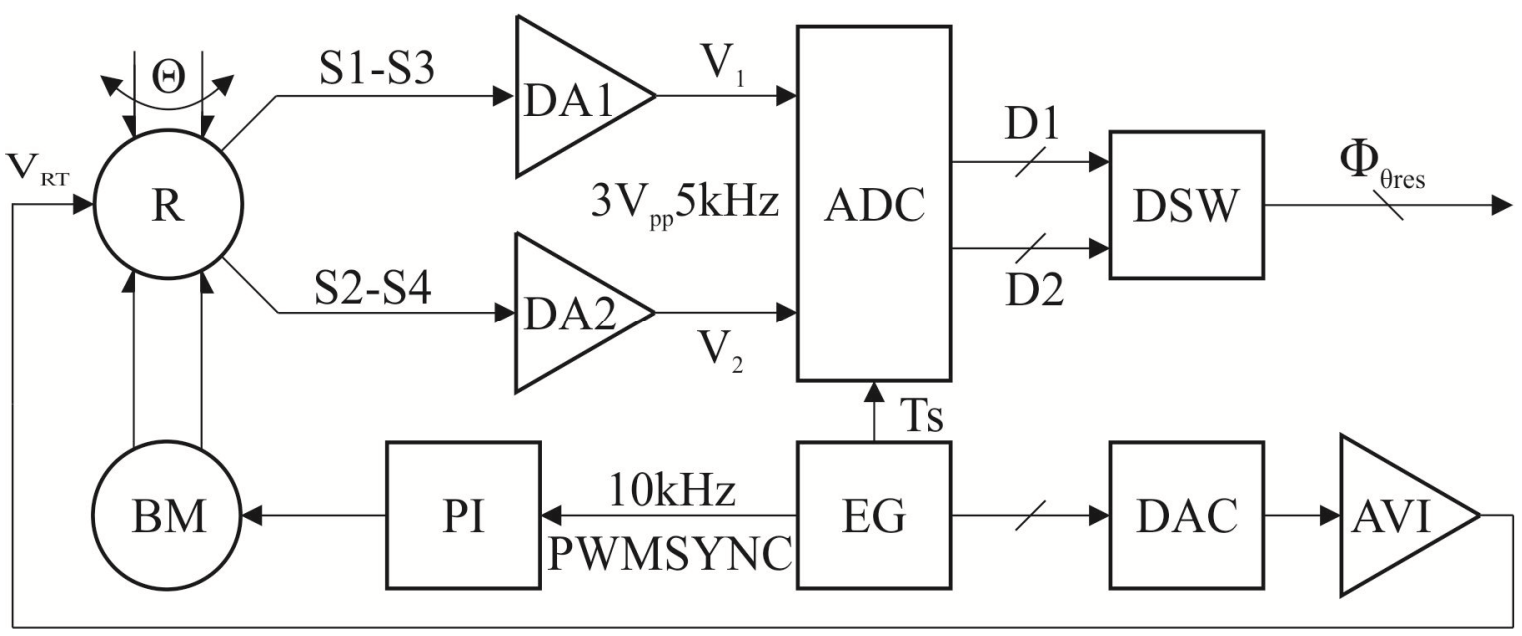

Fig. 3. Structure of the RDC with digital signal processor

An experiment has been set-up in order to validate the proposed solution. In this experiment, the modulation signal VRT and PWM noise were completely disappeared from the digital signals $D_{1}$ and $D_{2}$. For what concerns the accuracy of the position measurement, a comparison between the processed resolver data and the incremental encoder data has been performed. The tests were done with mechanical speeds of $0,01 \mathrm{rad} \cdot \mathrm{s}^{-1}$ and $50 \mathrm{rad} \cdot \mathrm{s}^{-1}$ respectively. Very small differences between the two measurements were achieved. An off line calculation allowed to evaluate that the overall measurement error of the proposed RDC was contained within the 12 bit ADC error ( 6 arc seconds of the rotating angle) and was speed independent.

The resolver and RDC working principle of is as follows Fig. 4. 


\section{Приборостроение, метрология}

The two output signals are modulated by the sine and cosine of the shaft angle. A graphical representation of the excitation signal and the sine and cosine output signals is shown in Fig. 4a. The sine signal has maximum amplitude at $90^{\circ}$ and $270^{\circ}$ and the cosine signal has maximum amplitude at $0^{\circ}$ and $180^{\circ}$.

On the Fig. $4 \mathrm{~b}$ the excitation current derivative $s I_{r R T}$, the PWM synchronism signal (PWMSYNC), sampling signal periods $T_{s}$, cosine signal of position cospres $\theta_{m e}$, output voltage $V_{1}$ and digital signal $D_{1}$ of 32-pole pair resolver after AD conversion by the motor speed of 937RPM and $T_{s}=100 \mu \mathrm{s}$.

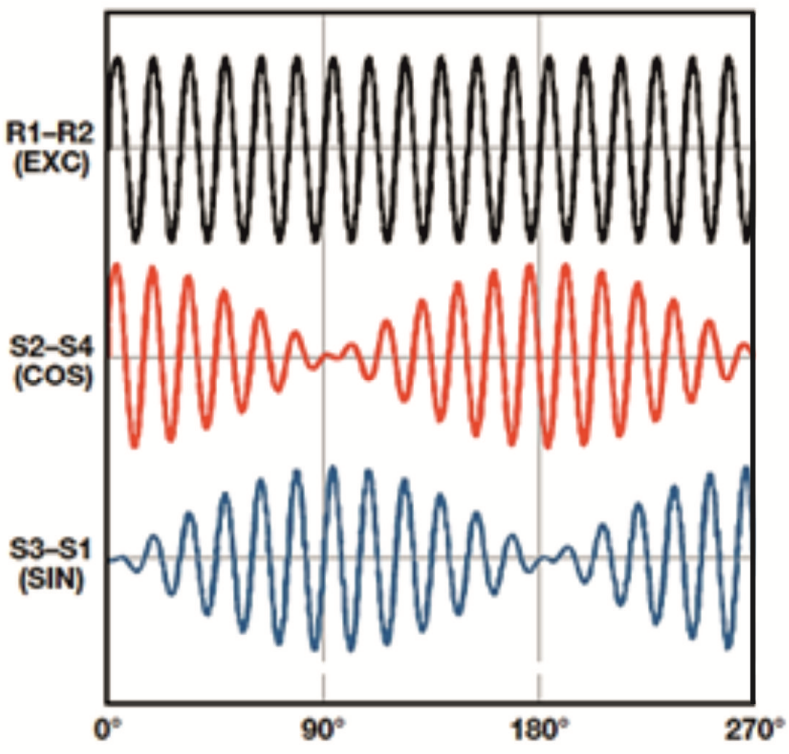

a)

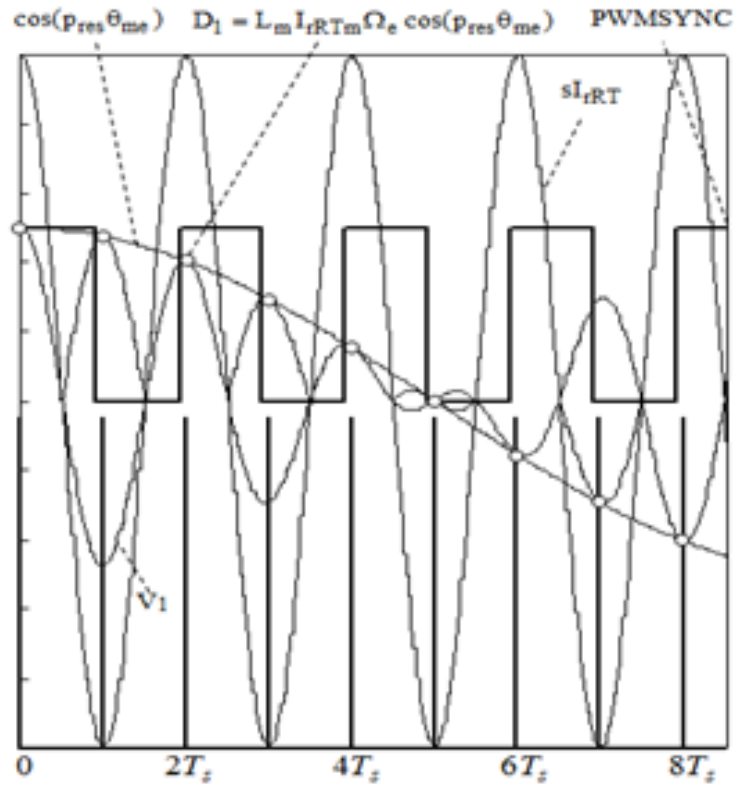

b)

Fig. 4. Resolver and RDC working principle

\section{The important feature RDC with digital signal processor}

The first important feature of the used method is tuning of excitation voltage $V_{R T}$ zero in the sampling period $\left(T_{s}\right)$ of DSP for getting the maximal amplitude of resolver output signals $V_{1}$ and $V_{2}$ in the sampling moments $T_{s}$. This tuning is done by the phase shift of $V_{R T}$ in the sampling period of the DSP during slow rotation of the motor. Tuning is finished by the maximum amplitude of signals $V_{1}$ and $V_{2}$ in the sampling moments $T_{s}$. Such procedure gives in the sampling moment the extremum of derivative of resolver rotor current $s I_{r R T}$, zero of resolver rotor current $\left(I_{r R T}=0\right)$ and zero back-EMFs in $V_{1}$ and $V_{2}-$ see (3) and (4).

The second important feature of the used method is synchronisation of $P W M$ synchronism signal $P W M S Y N C$ with founded moment of resolver excitation. The $P W M$ synchronism signal leading edge is tuned to get the minimal noise of measured signals. So, the system measures the resolver signals without being affected by the switching noise of inverter $P W M$. This phasing avoids the $P W M$ interference on the resolver signals.

The third important feature of the used method is double sampling per excitation period. Position data $D_{1}$ and $D_{2}$ are read each sampling period at the time moments when the output signals amplitude is maximal. By the next sampling, the position data $D_{1}$ and $D_{2}$ are read as $-V_{1}$ and $-V_{2}$. So, digital signals $D_{1}$ and $D_{2}$ after conversion will have the amplitude modulated waveform of the exciting signal corresponding to the rotating angle $\Theta_{\text {res }}=\Theta_{m e} p_{\text {res }}$ of the resolver as shown in Fig. 4b.

It is possible to calculate the angle, using a large number of known algorithms and various hardware $[2,3]$. The simplest of these algorithms is a four-quadrant arctan signal conversion: $\Theta_{m e} p_{\text {res }}=\operatorname{arctg}_{4}\left(V_{1} / V_{2}\right)$. 


\section{Calculation of the function $\operatorname{arctg}(\beta)$ by algorithmic and tabular methods}

The series expansion of the function $\operatorname{arctg}(\beta)$ is carried out on [17]:

$$
\operatorname{arctg}(\beta)=\sum_{k=0}^{\infty}(-1)^{k} \cdot \beta^{2 k+1} /(2 k+1) \text {. }
$$

In the range of angles from 0 to 45 degrees for resolution of 20 bits 5 first members of a row are enough, taken with a 32-bit accuracy. Thus, after the measurement with the ADC, the calculation of the angle and its representation in the form of 0 to 1 for values from 0 to $2 \pi$ takes 2 operations of normalization, one division, 5 multiplications, up to 8 additions and to 7 logical transitions on a short address. In total, no more than 40 cycles of a processor such as ARM Cortex-M3. For reduction of calculations Heron's formula is used. The calculations are integer (32 bits) with the normalization of up to 16 bits.

At calculation by the tabular method, the oktant with a required angle is determined by measured values of $V \sin$ and $V \cos$ and on the relation of values $|V \sin |$ and $|V \cos |$ the required angle is calculated by one of formulas [17]:

$$
\begin{aligned}
& \text { to } V \sin >0 \text { and } V \cos >0 \text { and }|V \sin |<|V \cos | \text {, then } \varphi=\beta, \\
& \text { to } V \sin >0 \text { and } V \cos >0 \text { and }|V \sin |>|V \cos | \text {, then } \varphi=\pi / 2-\beta \text {, } \\
& \text { to } V \sin <0 \text { and } V \cos >0 \text { and }|V \sin |>|V \cos | \text {, then } \varphi=-\beta \text {, } \\
& \text { to } V \sin >0 \text { and } V \cos >0 \text { and }|V \sin |<|V \cos | \text {, then } \varphi=-\pi / 2+\beta \text {, } \\
& \text { to } V \sin >0 \text { and } V \cos <0 \text { and }|V \sin |>|V \cos | \text {, then } \varphi=\pi / 2+\beta \text {, } \\
& \text { to } V \sin >0 \text { and } V \cos <0 \text { and }|V \sin |<|V \cos | \text {, then } \varphi=\pi-\beta \text {, } \\
& \text { to } V \sin <0 \text { and } V \cos <0 \text { and }|V \sin |<|V \cos | \text {, then } \varphi=-\pi+\beta \text {, } \\
& \text { to } V \sin <0 \text { and } V \cos <0 \text { and }|V \sin |>|V \cos | \text {, then } \varphi=-\pi / 2+\beta \text {, }
\end{aligned}
$$

where $\beta$ - an angle in the range of $0 \ldots 45$ degrees $(0 \ldots \pi / 4)$.

Further the value of $\operatorname{tg}(\beta)=|V \sin | /|V \cos |$ is calculated and according to the table, depending on $\operatorname{tg}(\beta 1)$, the value of $\beta 1$ is found, where $\operatorname{tg}(\beta 1)$ - the nearest smaller tabular value of a tangent of angle, and a required angle

$$
\beta=(\operatorname{tg}(\beta)-\operatorname{tg}(\beta 1))(C 0+C 1 \cdot \beta 1+C 2 \cdot \beta 1),
$$

where $C 0, C 1, C 2$ - correction coefficients of correction of the algorithm error function. Such method provides resolution of 16 bits at the table size in 256 values.

\section{Resolver-to-Digital Converter with arctangent ROM}

Application of DSC (Fig. 3) or ARM to evaluate the function $\beta=\operatorname{arctg} \beta$ within an octant in the algorithmic or tabular way leads to the reduction of the converting rate. Therefore, RDC with ROM should be preferred in high-speed MS. In MS, where "autophasing" [2] is not required, information on movement for self-switching of the electric motor can use the simplified algorithm of converting with $\operatorname{arctg}$ ROM. The offered [10] actantial representation of a full range of transformation, instead of a quadrant, at an equal speed allows to form additionally 3 highest weight discharge angles $\Theta$.This is important in case of creation of a two-speed RDC, in which an additional bit is used for the matching of fine and coarse reading of MS. Speed of the conversion of output signals of resolvers to the digital equivalent of movement is also defined by speed of $A D C$ of the relation of segments of tension in an octant.

In the scheme shown in Fig. 5 in the first stage output signals of resolver $R$ are converted to a code of a tangent of angle $\operatorname{tg} \beta=V_{s} / V_{c}$, where $\beta$ - the angle of rotation $\Theta$, given in the first octant. Simultaneously, the formation of three high-order digits of the angle $\Phi_{\Theta}$ is carried out. RDC works as follows. Two signals, proportional to the current value of $\sin S$ and $\cos C$ of the angle $\Theta$, arrive on inputs of the analog switchboard and the detector of octants $D O$.

Their preliminary conversion is carried out either by individual demodulators $D M$ of output signals of the resolver $R$ or by peak detectors of the "memory access" type [10]. Three high-order digits of the code of the angle $\Theta$ are formed from the number of the octant. By comparison of output signals of the resolver $R$ with each other and with a zero-level number of the octant is defined, which contains 


\section{Приборостроение, метрология}

the angle of rotation of a shaft of the resolver $R$. The octant in which $\sin \Theta>0, \cos \Theta>0$, and $\sin \Theta<\cos \Theta$ is accepted to be the first. Number of the octant increases counterclockwise. According to the known number of the octant signals, proportional to $\sin$ and $\cos$ of the angle $\Theta$ in the first octant, are determined:

$\sin \beta=|\sin \Theta|, \cos \beta=|\cos \Theta|$ in the $1,4,5$ and 8th octants;

$\sin \beta=|\cos \Theta|, \cos \beta=|\sin \Theta|-$ in the 2, 3, 6 and 7 th octants.

By linear analogue-to-digital conversion the code of the tangent of an angle $\beta$ is defined, while as a reference signal in $A D C$ is used a signal proportional to $\cos \beta$, and as a measuring signal $-\sin \beta$.

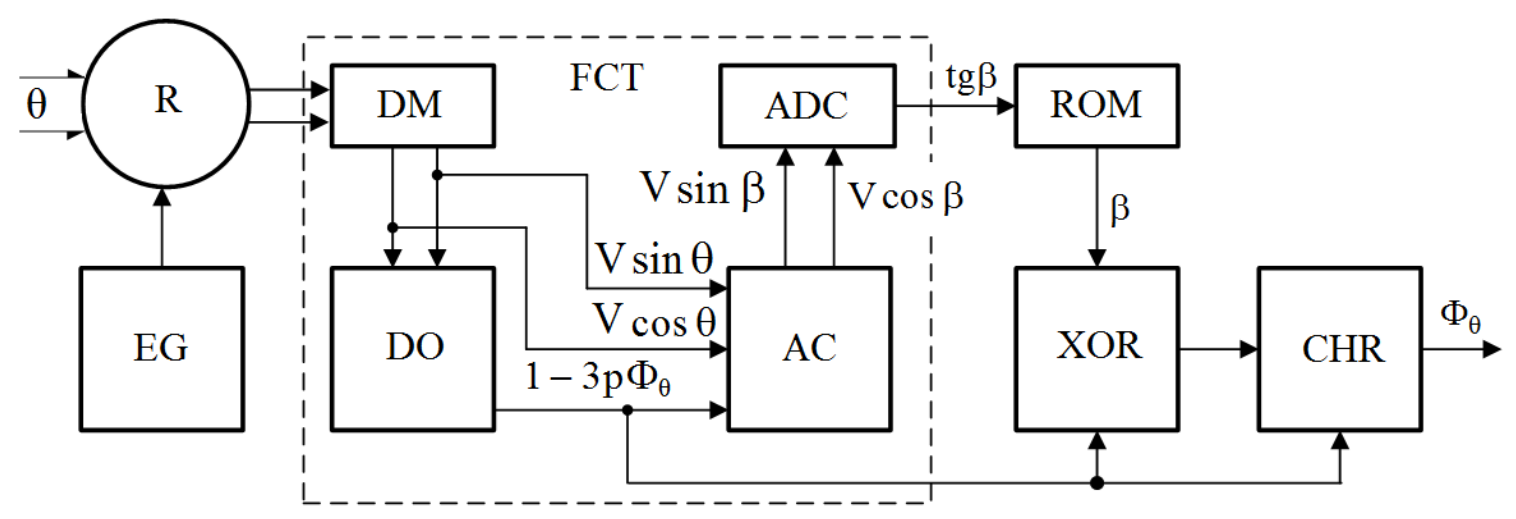

Fig. 5. Structure of the RDC with arctangent ROM

Construction of FCT on integrated circuits is considered in [12]. From the output $A D C$ the code of $\operatorname{tg} \beta$ arrives to address inputs of the read-only memory $R O M$, programmed under the law of the arctangent in the range of corners $0-\pi / 4$. ROM provides functional transformation of the input value $\operatorname{arctg}(\operatorname{tg} \beta)=\beta$, i.e. outputs the code of the angle $\beta$. A maximum code of the angle $\beta$ corresponds to a zero input code $\operatorname{tg} \beta M_{\max }=2^{j}-1$, where $j$ - a digit capacity of $R O M$. The code of the tangent of a given angle $\beta$ arrives at the address inputs of the ROM, which is used in a conversion device of the code $\operatorname{tg} \beta$ to the parameter code $\beta$.

The code of the angle $\beta$ is inputs to the EXCLUSIVE OR scheme $(X O R)$, the other input of which is controlled by the least significant digit code of octants. Thus, in odd octants with the least significant digit code of octants equal to zero, $X O R$ outputs the true code of the angle $\beta$, and in even octants with the least significant digit code of octants equal to one, it outputs the inverse code of the angle $\beta$, supplementing the angle $\beta$ to $\pi / 4$, i.e. equal to $(\pi / 4-\beta)$. From the output of XOR the code of the angle $\beta$ or $(\pi / 4-\beta)$ goes to one of the inputs of the code holding registers $C H R$ (see Fig. 5), to the other input of witch comes the code of octants from $D O$. As a result of the summation of codes $C H R$ outputs the code of the angle $\Phi_{\Theta}$.

More than two-fold increase in conversion accuracy is achieved at simultaneous simplification of its circuit construction. Reducing of an instrumental error component by eliminating the additional code converter - the voltage gives an increase in the accuracy not less than in two times, and the exclusion of methodological error component allows further increasing of the conversion accuracy.

From the point of view of simplification the use of the one ADC and application of only standard integrated circuits is important, which reduces its cost. A significant advantage of such construction is its feasibility on standard electronic elements without the use of additional correcting ROM logic devices, which leads to the simplification of the device and improves the technological effectiveness of its production. An important factor is also the economy of ROM capacity, which at the same digit capacity of the output code is not less than $25 \%$ in comparison with sine-cosine RDC. At pulse powering of ROM the power consumption reduces, thereby implementing the device as a module based on the integrated or hybrid technology. 


\section{Conclusion}

The progress in the sphere of RDC is caused by the improvement of technological processes and the development of new circuit solutions. The creation of integrated devices working at high speed and resolving power gives a number of advantages, including the reduction of the cost of products and the expansion of their functionality [7, 10].

Formation of digital equivalents of components of movement and its speed by the known RDC allows to give to the mechatronic system advantages of adaptation and self-organization [11], artificial intelligence, optimization of movement on time. To implement a modal [2], robust [6] and profile [2,4] control it is necessary to increase the efficiency of MS energyinformatics.

Replacement of the elementary differential link which is traditionally used in all structures of automatic regulation to the more "intelligent" statistical link of a mathematical regression analysis of previous values is recommended. Ideologically differing from the well-known Kalman filter, link of this type allows to form in real time the current value of a control error by means of the mathematical regression analysis of all of its previous values, and thereby eliminate the influence of random fluctuations of signals in a feedback loop on the conversion accuracy. The synthesized digital tracking algorithm with a statistical link of regression processing allows to authentically receive up to 20 bits of the binary code of the angle measured by the angle-component solver [9]. The options of converting presented in the work indicate that modern microelectronics along with a sensor, having properties of a chronotope, fall within the postulate on spatio-temporal relation of the general theory of relativity, which was announced in 1916 by Albert Einstein [20].

\section{References}

1. Energoinformatika. Bol'shaya entsiklopediya [Energoinformatic. Grand Encyclopaedia]. Moscow, Terra Publ., 2006, vol. 60. 440 p.

2. Balkovoy A.P., Tsatsenkin V.K. Pretsizionnyy elektroprivods ventil'nymi vigatelyami [Precision Drive with the Brushless Motor]. Moscow, MEU Publ., 2010. 328 p.

3. Balkovoi A.P., Kallenbach E. A Low Cost RDC. Proc. of the 49th International Scientific Colloquium, Technical University of Ilmenau, 2004, pp. 338-342.

4. Drury B. The Control Techniques Drives and Controls: Handbook, 2nd Edition, EMERSON. JET, 2009. $724 \mathrm{p}$.

5. Cronacher G. Design, Performance and Application of the Vernier Resolver. The Bell System Technical Journal, issue XXXVI, vol. 6, 1957, pp. 103-112.

6. Szymczak J., O’Meara Sh., Gealon J., De La Rama C. Precision Resolver-to-Digital Converter Measures Angular Position and Velocity. Analog Dialogue, 48-03, March, 2014, pp. 1-6.

7. Smirnov Yu.S. Elektromekhatronnye preobrazovateli [Electromechatronic Converters]. Chelyabinsk, South Ural St. Univ. Publ., 2013. 361 p.

8. Spetzer J., Ekhaml W. Resolvers. Things You Need to Know about Sizing and Applying. Motion System Design, March, 2001, pp. 61-64.

9. Smirnov Y.S., Safronov V.V., Anisimov Y.O. Common Dateware Mechatronic with Resolver-toDigital Convertor. International Conference on Industrial Engineering, ICIE 2015. Procedia Engineering, 2015, vol. 129, pp. 736-742.

10. Safronov V.V. [Theory and Practice Using of the Encoders Based on Sine-Cosine Rotary Transformer]. Components and Technologies, 2014, no. 4, pp. 26-30. (in Russ.)

11. Smirnov Y.S. Common Dateware of Robotics Mechatronic Converters. Proc. of the Third ISMCR'93, Italy, Torino, 1993, As 1, pp. 13-18.

12. Domrachev V.G., Matveevskiy V.R., Smirnov Yu.S. Skhemotekhnika tsifrovykh preobrazovateley peremeshcheniy [Circuit Design of Digital Converters Displacements]. Moscow, Energoatomizdat Publ., 1987. 392 p.

13. Goodenough F. ICs Dictate Motor Shaft Position, Velocity and Acceleration. Electronic Design, 1988, vol. 36, no. 3, pp. 52-53.

14. Domrachev V.G., Smirnov Y.S. Tsifroanalogovyie sistemyi pozitsionirovaniya. Elektromehanotronnyie preobrazovateli [Digital-to-Analog Positioning Systems. Electromechatronic Converters], Moscow, Energoatomizdat Publ., 1990, 240 p. 


\title{
Приборостроение, метрология
}

15. Sposob izmereniya ugla povorota vala privoda i ustroystvo dlya ego realizatsii [Method for Measuring the Angle of Rotation of the Shaft and a Drive Device for its Realization]. Patent RF no. 2580153. Available at: http://www.findpatent.ru/patent/ 258/2580153.html/ (accessed 15 June 2016).

16. Sylvan J. New Option for Resolver-to-Digital Conversion. Machine Design, 1987, October, pp. 141-146.

17. Anufriev V., Luzchbinin A., Shumilin S. [Signal Processing Techniques of Inductive Sensors of the Linear and Angular Displacement]. Modern electronics, 2014, no. 4, pp. 30-33. (in Russ.)

18. Balkovoy A., Slivinskaia G. Sinusoidal Incremental Encoder Date Processing. Proceedings of the 48th International Scientific Colloquium. Technical University of Ilmenau, 2003, p. 111.

19. Smirnov Yu.S., Yurasova E.V., Vstavskaya E.V., Nikitin I.S. [Specificity of Application of Sine-Cosine Sensors]. Materialy konferentsii "Informatsionnye tekhnologii v upravlenii" (ITU-2014) [Materials of Conference "Information Technologies in Management"]. St. Petersburg, Russia, 2014, pp. $720-728$.

20. Nauka. Velichayshie teorii: vypusk 1: Prostranstvo - eto vopros vremeni. Eynshteyn. Teoriya otnositel'nosti [Science. The Great Theory: Issue 1: The Space - it's a Matter of Time. Einstein. Theory of Relativity]. Moscow, De Agostini, 2015. 176 p.

Received 10 May 2016

\section{ПРЕОБРАЗОВАТЕЛИ «УГОЛ - ПАРАМЕТР - КОД» С АРКТАНГЕНСНЫМ ФУНКЦИОНАЛЬНЫМ ПРЕОБРАЗОВАНИЕМ}

\author{
А.П. Балковой ${ }^{1}$, Е.В. Юрасова ${ }^{2}$, Ю.С. Смирнов ${ }^{2}$ \\ ${ }^{1}$ Московский энергетический институт, г. Москва, \\ 2 Южно-Уральский государственный университет, г. Челябинск
}

Работа посвящена рассмотрению особенностей построения амплитудных преобразователей «угол-параметр-код», в которых при конвертации выходных сигналов резольвера в цифровой эквивалент перемещения применяется арктангенсное функциональное преобразование. Рассмотрены особенности построения классического бесконтактного резольвера и его разновидности - редуктосина, которые позволяют реализовать электрическую редукцию, существенно повышающую точность сенсора. Раскрыт принцип действия резольвера, выходные сигналы которого содержат достоверную информацию о составляющих перемещения ротора. Преобразователь «угол-параметр-код» соответствует постулату общей теории относительности о связи пространства и времени.

Особое место среди однокомпонентных преобразователей «угол-параметр-код» занимают структуры, использующие арктангенсное функциональное преобразование, при котором используется квадрантное или октантное разбиение диапазона преобразования углового перемещения. В первом случае тригонометрическое преобразование реализуется цифровым сигнальным процессором или микроконтроллером, а во втором - посредством ПЗУ с арктангенсной прошивкой. Приведена структура и соотношения, необходимые для вычисления перемещения путем программной и табличной реализации арктангенсной функции. Представлен оригинальный вариант аналого-цифрового преобразователя с арктангенсной ПЗУ. Его емкость при одинаковой разрядности выходного кода в четыре раза меньше емкости традиционно используемого ПЗУ с синусно-косинусной прошивкой. Октантное представление полного диапазона преобразования угла поворота, позволяет сформировать дополнительный старший разряд выходного кода по сравнению с традиционным квадрантным разбиением диапазона. Это позволяет не только повысить разрешение преобразования 
в 2 раза, но и упростить согласование отсчетов при применении электрической редукции с редуктосином.

Ключевые слова: преобразователь «угол-параметр-код», классический и верньерный резольвер резольверы, широтно-импульсная модуляция, арктангенсное функииональное преобразование, АЦП отношения напряжений, постоянное запоминающее устройство.

\section{Литература}

1. Энергоинформатика. Большая энщиклопедия: в 62 m. - М.: ТЕРРА, 2006. - T. 6. - С. 440.

2. Балковой, А.П. Прецизионный электропривод с вентильными двигателями / А.П. Балковой, В.К. Цаченкин. - М.: ИД МЭИ, 2010. - 328 с.

3. Balkovoi, A.P. A low cost RDC / A.P. Balkovoi, E. Kallenbach // Proc. of the 49th International Scientific Colloquium, Technical University of Ilmenau. - 2004. - P. 338-342.

4. Drury, B. The Control Techniques Drives and Controls: Handbook / B. Drury. - 2nd ed. EMERSON. JET, 2009. - 724 p.

5. Cronacher, G. Design, performance and application of the Vernier resolver / G. Cronacher // The Bell System Technical Journal. - 1957. - Iss. XXXVI, vol. 6. - P. 103-112.

6. Precision Resolver-to-Digital Converter Measures Angular Position and Velocity / J. Szymczak, Sh. O'Meara, J. Gealon, C. De La Rama // Analog Dialogue. - 2014. - 48-03, March. - P. 1-6.

7. Смирнов, Ю.С. Электромехатронные преобразователи / Ю.С. Смирнов; под ред. А.Л. Шестакова. - Челябинск: Издат. иентр ЮУрГУ, 2013. - 360 с.

8. Spetzer, J. Resolvers. Things you need to know about sizing and applying / J. Spetzer, W. Ekhaml // Motion System Design. - 2001. - March. - P. 61-64.

9. Smirnov, Y.S. Common Dateware Mechatronic with Resolver-to-Digital Convertor / Y.S. Smirnov, V.V. Safronov, Y.O. Anisimov // International Conference on Industrial Engineering, ICIE 2015. Procedia Engineering. - 2015. - Vol. 129. - P. 736-742.

10. Сафронов, В.В. Теория и практика применения датчиков угла поворота на основе СКВТ / В.В. Сарронов // Компоненты и технологии. - 2014. - № 4. - С. 26-30.

11. Smirnov, Y.S. Common Dateware of Robotics Mechatronic Converters / Y.S. Smirnov // Proceedings of the Third ISMCR'93. Torino, Italy, 1993. - P. 13-18.

12. Домрачев, В.Г. Схемотехника иифровых преобразователей перемещений / В.Г. Домрачев, В.Р. Матвеевский, Ю.С. Смирнов. - М.: Энергоатомиздат, 1987. - 392 с.

13. Goodenough, F. ICs dictate motor shaft position, velocity and acceleration / F. Goodenough // Electronic Design. - 1988. - Vol. 36, no. 3. - P. 50-52.

14. Домрачев, В.Г. Цифроаналоговые системы позиционирования. Электромеханотронные преобразователи / В.Г. Домрачев, Ю.С. Смирнов. - М.: Энергоатомиздат, 1990. - 240 с.

15. Способ измерения угла поворота вала привода и устройство для его реализации: пат. 2580153 Российская федераџия, G01B7/30 / В.B. Сафронов; заявитель и патентообразователь ФГУП «ЦНИИМаш». - Заявл. 25.11.14; опубл. 10.04.16, Бюл. № 10. - С. 3.

16. J. Sylvan. New Option for Resolver-to-Digital Conversion. Machine Design,1987, October, pp. 141-146.

17. Ануфриев, В. Методы обработки сигналов индуктивных датчиков линейных и угловых перемещений / В. Анурриев, А. Лужбинин, С. Шумилин // Современная электроника. - 2014. № 4. - C. 30-33.

18. Balkovoy, A. Sinusoidal incremental encoder date processing / A. Balkovoy, G. Slivinskaia // Proceedings of the 48th International Scientific Colloquium. Technical University of Ilmenau, 2003. P. 111 .

19. Специфика применения синусно-косинусных сенсоров / Ю.С. Смирнов, Е.В. Юрасова, Е.В. Вставская, И.С. Никитин // Материалье конференции «Информационные технологии в управлении» (ИТУ-2014). - СПб.: ОАО «Концерн «ЦНИИ «Электроприбор», 2014. - С. 720-729.

20. Наука. Величайшие теории: вып. 1: Пространство - это вопрос времени. Эйнштейн. Теория относительности. - М.: Де Агостини, 2015. - 176 с. 


\section{Приборостроение, метрология}

Балковой Александр Петрович, канд. техн. наук, старший научный сотрудник, кафедра автоматизированного электропривода, Московский энергетический институт, г. Москва; balk1954@, yahoo.com.

Юрасова Екатерина Валерьевна, канд. техн. наук, доцент, доцент кафедры информационно-измерительной техники, Южно-Уральский государственный университет, г. Челябинск; iurasovaev@ susu.ru.

Смирнов Юрий Сергеевич, д-р техн. наук, профессор, профессор кафедры приборостроения, Южно-Уральский государственный университет, г. Челябинск; smirnovys@susu.ru.

Поступила в редакцию 10 мая 2016 2.

\section{ОБРАЗЕЦ ЦИТИРОВАНИЯ}

Balkovoy, A.P. Resolver-to-Digital Converters with the Arctangent Function Transformation / A.P. Balkovoy, E.V. Yurasova, Yu.S. Smirnov // Вестник ЮУрГУ. Серия «Компьютерные технологии, управление, радиоэлектроника». - 2016. - Т. 16, № 3. - С. 83-92. DOI: $10.14529 /$ ctcr160309

\section{FOR CITATION}

Balkovoy A.P., Yurasova E.V., Smirnov Yu.S. Resolver-to-Digital Converters with the Arctangent Function Transformation. Bulletin of the South Ural State University. Ser. Computer Technologies, Automatic Control, Radio Electronics, 2016, vol. 16, no. 2, pp. 83-92. DOI: $10.14529 /$ ctcr160309 